\title{
IDENTIFIKASI GEJALA STRES KLIEN DI YAYASAN RUMAH ORBIT SURABAYA SELAMA PROSES REHABILITASI
}

\author{
Nurma Yulya Sari \\ Jurusan Bimbingan dan Konseling, Fakultas Ilmu Pendidikan, Universitas Negeri Surabaya \\ nurmayulya12@gmail.com
}

\begin{abstract}
Abstrak
Stres merupakan tanggapan seseorang, baik secara fisik maupun secara psikologis terhadap suatu perubahan di lingkungannya yang dirasakan mengganggu dan mengakibatkan dirinya terancam. Untuk mengetaui seseorang mengalami stres perlu mengetahui gejala stres terlebih dahulu. Latar belakang penelitian ini dilakukan untuk mengurangi kasus bunuh diri klien mantan pengguna narkoba saat proses rehabilitasi. Sehingga diperlukan untuk mengetahui gejala stres terlebih dahulu. Penelitian ini termasuk jenis penelitian studi literatur dengan mencari referensi teori yang relefan dengan kasus atau permasalahan yang ditemukan. Referensi teori yang diperoleh dengan jalan penelitian studi literatur dijadikan sebagai fondasi dasar dan alat utama bagi praktek penelitian ditengah lapangan. Penelitian ini dilakukan di Yayasan Rumah Sehat Orbit. Analisis hasil penelitian dilakukan dengan cara menganalisis, membandingkan standart tingkat stres dengan gejala gejala yang dialami oleh klien pada saat rehabilitasi. Hasil penelitian menunjukkan bahwa klie di Yayasan Orbit Surabaya mengalami stress pada tahap ke III dengan gejala Gangguan lambung semakin terasa nyata misalkan maag, ketegangan otot semakin terasa, perasaan ketidaktenangan dan ketegangan emosional semakin meningkat, gangguan pola tidur, badan terasa lelah, mudah sakit.
\end{abstract}

Kata kunci: Stres, Studi dokumentasi, Rehabilitasi.

\section{Abstract}

Stress is a response to a person, both physically and psychologically to a change in the environment that is perceived to be disturbing and causing him/her to be threatened. To know someone experiencing stress need to know the symptoms of stress first. The background of this study was conducted to reduce the cases of suicide clients former drug users during the rehabilitation process. So it is necessary to know the symptoms of stress first. This study includes a type of literature study research by finding reference to the theory relevant to cases or problems found. Reference theory obtained by way of research literature study serve as the basic foundation and the main tool for research practice in the field. The study was conducted at the Orbit Healthy Home Foundation. Analysis of the results of research conducted by analyzing, comparing the standard of stress level with symptoms experienced by clients at the time of rehabilitation. The results showed that the client at Orbit Foundation Surabaya experienced stress at the third stage with symptoms of gastric disturbance was felt like an ulcer, muscle tension increasingly felt, feelings of unrest and emotional tension is increasing, disturbance of sleep patterns, body feels tired, easily sick.

Keywords: Stress, Documentation Study, Rehabilitation

Copyright@2017 Jurusan Bimbingan dan Konseling, Universitas Negeri Surabaya

\section{PENDAHULUAN}

Penyalahgunaan Narkotika, Psikotropika, dan Zat Adiktif lainnya (NAPZA) atau istilah yang lebih dikenal banyak orang dengan sebutan NARKOBA (Narkotika dan Obat - obat berbahaya) semakin marak terjadi dengan berbagai macam permasalahan yang kompleks. Kasus penyalahgunaan narkoba seperti tidak ada habisnya. Setiap tahun angka penyalahgunaan narkoba tidak mengalami penurunan atau bahkan kestabilan melainkan terjadi peningkatan angka penyalahgunaan narkoba. Berdasarkan pendataan dari aplikasi Sistem Informasi Narkotika (SIN) dalam

(file:///C:/Users/USER/Downloads/infodatin\%20na rkoba\%202017\%20(1).pdf) jumlah kasus narkotika yang berhasil diungkap mulai tahun 2012-2016 pertahun sebesar $76.53 \%$. kenakan paling tinggi pada tahun 2013 ke tahun 2014 yaitu 161.22\%. tahun 2016 jumlah kasus narkotika yang behasil diungkap adalah 868 kasus, jumlah ini meningkat $36.05 \%$ dari tahun 2015 seperti tampak pada gambar grafik berikut ini : 


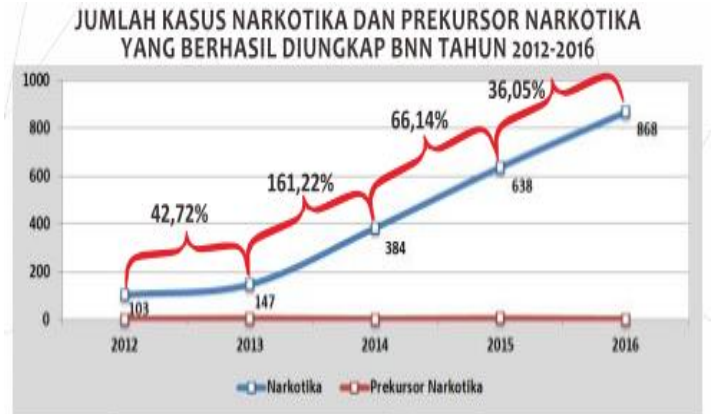

Gambar 1.1

Dari gambar 1.1 dapat dilihat setiap tahun mengalami peningkatan penyalahgunaan narkoba. Sedangkan pada tahun 2017 ini menurut Kabag Humas BHH, Kombes yaitu Bapak Sulistiandriyatmoko menyebutkan bahwa sudah terjadi 423 kasus penyalahgunaan narkoba dari bulan Januari hingga bulan Juli 2017.

Angka peningkatan penyalahgunaan narkoba juga dapat menggambarkan keadaan disalah satu yayasan rehabilitasi di Kota Surabaya yaitu Yayasan Rumah Sehat Orbit Surabaya yang setiap bulannya ada yang keluar karena sudah pulih dan ada yang masuk untuk mendapatkan perawatan untuk proses pemulihan. Bagi klien yang baru saja masuk ke panti rehabilitasi pasti membutuhkan waktu untuk mampu menerima keadaan yang sudah terjadi dan juga menyesuaikan diri.

Menurut (KBBI) Kamus Besar Bahasa Indonesia definisi rehabilitasi merupakan pemulihan kepada kedudukan (keadaan, nama baik) yang dahulu (semula); perbaikan anggota tubuh yang cacat dan sebagainya atas individu (misalnya pasien rumah sakit, korban bencana) supaya menjadi manusia yang berguna dan memiliki tempat dalam masyarakat.

Undang-Undang Nomor 35 Tahun 2009 Pasal 103 ayat (2) tentang Narkotika menjelaskan bahwa rehabilitasi terhadap pecandu narkotika adalah suatu proses pengobatan untuk membebaskan pecandu dari ketergantungan, dan masa menjalani rehabilitasi tersebut diperhitungkan sebagai masa menjalani hukuman. Sehingga dapat disimpulkan bahwa rehabilitasi adalah usaha pemulihan korban narkotika sehingga kembali dapat melaksanakan fungsionalitas sosialnya yaitu dapat melaksanakan tugas hidupnya secara normal dan wajar.

Selama proses rehabilitasi, klien tidak bisa terlepas dengan yang namanya stres. Atkinson (2000) dalam Nursalim (2013) Stres menunjuk pada peristiwa yang dirasakan membahayakan individu, saat individu diharapkan pada situasi stress, maka individu akan bereaksi baik secara fisiologis maupun psikologis. Pendapat Lazarus (1999) dalam Nursalim (2013) menganggap stress sebagai sebuah gejala yang timbul akibat adanya kesenjangan antara realitas dan ideal, antara keinginan dan kenyataan, antara tantangan dan kemampuan, antara peluang dan potensi. Lazarus juga menyatakan bahwa stress adalah peristiwa peristiwa fisik maupun psikologis yang dipersepsikan sebagai ancaman potensial terhadap gangguan fisik maupun secara emosional. Jadi dapat disimpulkan bahwa stress merupakan tanggapan seseorang, baik secara fisik maupun secara psikologis terhadap suatu perubahan di lingkungannya yang dirasakan mengganggu dan mengakibatkan dirinya terancam.

Saat ini banyak kasus yang terjadi salah satunya bunuh diri yang diakibatkan karena stres. Dalam berita Inilah.com, Jakarta - Menteri Hukum dan HAM Yasonna Laoly menduga napi narkoba bunuh diri karena takut masa bebasnya yang tinggal dua bulan lagi akan dicabut jika terbukti bertransaksi narkoba. Dari berita tersebut kita tahu bahwa kasus bunuh diri memungkinkan dilakukan oleh pengguna narkoba. Untuk menghindari dan mengurangi hal tersebut terjadi upaya yang bisa dilakukan yaitu mengenali gejala gejala stres sehingga jika ditemukan ada klen yang mengalami stres segerapa mendapat pelayanan untuk menurunkan tingkat stres. Hal itulah yang mendasari dan menjadi latar belakang penelitian identifikasi gejala stres yang dialami oleh klien di Yayasan Rumah Sehat Orbit Surabaya.

Sebelumnya ada penelitian yang dilakukan oleh Nawangsih dan Putri Rismala (2016) Fakultas Psikologi Universitas Semarang dengan judul Stres Pada Mantan Pengguna Narkoba Yang Menjalani Rehabilitasi, dengan rincian : penelitian ini menggunakan metode kualitatif fenomenologis yang bertujuan untuk memahami stres pada mantan pengguna narkoba yang menjalani rehabilitasi. Penelitian ini mengungkap faktor-faktor yang memengaruhi stres dan akibat dari stres yang dialami oleh mantan pengguna narkoba yang menjalani rehabilitasi. Faktor-faktor yang memengaruhi mantan pengguna narkoba mengalami stres selama menjalani rehabilitasi antara lain hilangnya kebebasan, perasaan bersalah, sanksi sosial seperti label mantan pengguna narkoba serta sanksi-sanksi lainnya yang kemudian memperburuk kondisi. Adapun stres yang dialami tersebut lebih lanjut memberikan akibat terhadap kondisi subjektif, perilaku, kognitif, dan fisiologis pada mantan pengguna narkoba.

Untuk mengetahui klien mengalami stres atau tidak perlu mengenali gejala - gejalanya. Taylor (1991) menyatakan stres dapat menghasilkan berbagai respon. Berbagai peneliti telah membuktikan bahwa respon-respon tersebut dapat berguna sebagai indikator terjadinya stres pada individu dan mengukur tingkat stres yang dialami individu. Manusia bereaksi seutuhnya, artinya terdapat gejala-gejala fisik maupun psikis stres dapat dibagi sebagai berikut :

a. Gejala Fisik

Gejala fisik meliputi keadaan merasa lelah, imsomnia, nyeri kepala, otot kaku dan tegang, 
berdebar-debar, nyeri dada, nafas pendek, gangguan lambung dan pencernaan, mual, gemetar, tangan dan kaki merasa dingin, wajah terasa panas, berkeringat, sering flu, dan menstruasi terganggu. Karena gejala fisik ini mungkin ada kaitannya dengan penyakit fisik sebaiknya berkonsultasi dengan dokter sebelum memutuskan bahwa gejala fisik tersebut disebabkan oleh stres.

b. Gejala Psikis

Keadaan psikis ini ada 3 bagian : Gejala Mental : Gejala mental meliputi berkurangnya konsentrasi dan daya ingat, ragu-ragu, bingung, merasa pikiran penuh atau bahkan merasa kosong, kehilangan rasa humor. Gejala Emosi : meliputi cemas (berbagai situasi), depresi, putus asa, mudah marah, ketakutan, frustasi, tiba-tiba menangis, fobia, rendah diri, merasa tidak berdaya, menarik diri dari pergaulan, dan menghindari kegiatan yang sebelumnya disenangi. Gejala Perilaku : Gejala perilaku ini meliputi gejala yang ditunjukkan oleh individu yang merasa stress seperti, mondarmandir, gelisah, menggigit kuku, menggerakgerakkan anggota badan/jari- jari, perubahan pola makan, merokok, minum-minuman keras, menangis histeris, berteriak, mengumpat, melempar barang atau memukul barang.

\section{METODE PENELITIAN}

Penelitian ini termasuk jenis penelitian studi literatur dengan mencari referensi teori yang relefan dengan kasus atau permasalahan yang ditemukan. Referensi teori yang diperoleh dengan jalan penelitian studi literatur dijadikan sebagai fondasi dasar dan alat utama bagi praktek penelitian ditengah lapangan.

Penelitian ini dilakukan di Yayasan Rumah Sehat Orbit Surabaya. Jenis data yang digunakan penulis dalam penelitian ini adalah data primer dengan melakukan wawancara, obervasi dan data sekunder yaitu data yang diperoleh dari jurnal, buku dokumentasi, dan internet.

Data-data yang sudah diperoleh kemudian dianalisis dengan metode analisis deskriptif. Metode analisis deskriptif dilakukan dengan cara mendeskripsikan fakta-fakta yang kemudian disusul dengan analisis, tidak semata-mata menguraikan, melainkan juga memberikan pemahaman dan penjelasan secukupnya.

\section{HASIL PENELITIAN DAN DISKUSI}

Penelitian yang dilakukan oleh Nawangsih dan Putri Rismala (2016) Fakultas Psikologi Universitas Semarang dengan judul Stres Pada Mantan Pengguna Narkoba Yang Menjalani Rehabilitas yang sudah disinggung diatas hasilnya menunjukkan bahwa mantan pengguna narkoba yang menjalani rehabilitasi mengalami stres dikarenakan oleh beberapa faktor diantaranya latar belakang pengalaman, karakteristik stresor, dan karakteristik kepribadian. Stres yang muncul berakibat pada subjek mantan pengguna narkoba yang menjalani rehabilitasi, diantaranya akibat secara subjektif, perilaku, kognitif, dan fisiologis.

Hasil penelitian yang dilakukan oleh Lisdiana (2012) yang berjudul Regulasi Kortisol Pada Kondisi Stres Dan Addiction diketahui bahwa kadar kortisol pada Addict recoverymenunjukkan rerata kadar yang masih dalam range normal dengan urutan kadar kortisol tertinggi pada pengukuran pertama pada kelompok Addict recoveryyang tidak menjalani rehabilitasi. Kadar kortisol terendah dijumpai pada pengukuran kedua atau setelah menjalani rehabilitasi. Hal ini dapat dijelaskan sebagai berikut, bahwa tubuh akan bereaksi terhadap stres dengan mengeluarkan dua jenis zat kimia yakni hormon dalam darah dan neurotransmitter di otak. Hal ini sesuai dengan pernyataan Stocker (2012), bahwa stres merupakan faktor utama dalam menyebabkan kambuh di semua kecanduan. Stres dapat berupa banyak bentuk. Pada kondisi addict, dimana seseorang dalam kondisi emosi negatif, gelisah, cemas. Kondisi ini akan menyebabkan sekresi CRF oleh hipotalamus meningkat, peningkatan kadar CRF akan memicu peningkatan kadar ACTH oleh pituitary, pada akhirnya akan mengaktifkan korteks adrenal sehingga sekresi glukokortikoid terutama kortisol meningkat (Cance et al.1994; Dunn 1995; Bear et al.1996). CRF telah ditunjukkan untuk mendorong perubahan perilaku yang berkaitan dengan berbagai adaptasi terhadap stres. Disregulasi dari sistem CRF pada titik tertentu dapat menyebabkan berbagai gangguan kejiwaan, termasuk gangguan kejiwaan akibat penggunaan narkotika (Haass \& Bartlett 2012).

Penelitian yang dilakukan oleh Hanum (2016) yang berjudul Penerapan Manajemen Stres Berkelompok dalam Menurunkan Stres pada Lanjut Usia Berpenyakit Kronis. Hasil penelitian tersebut membuktikan bahwa program intervensi manajemen stres secara berkelompok mampu menurunkan tingkat stres yang dialami oleh lansia penderita penyakit kronis. Penelitian ini bertujuan untuk melihat efek dari penerapan manajemen stres secara berkelompok dalam menurunkan stres pada lansia penderita penyakit kronis. Untuk mencapai tujuan tersebut, penelitian in menggunakan desain quasi-experimentalone-group pre-test post-test dengan within-group analysis. Populasi yang menjadi sasaran dalam penelitian ini adalah lansia berpenyakit kronis. Jumlah partisipan dalam penelitian ini adalah 64 orang yang dibagi ke dalam lima kelompok berdasarkan lokasi tempat tinggal mereka. Pre-test dan post-test pada seluruh kelompok dilakukan dengan menggunakan alat ukur Perceived Stress Questionnaire (PSQ) dan hasilnya dianalisis dengan metode Paired Sample T-Test. Hasil penelitian ini menunjukkan bahwa 
program manajemen stres berkelompok dapat menurunkan stres yang dialami oleh partisipan. Oleh karena itu, dapat disimpulkan bahwa program intervensi ini dapat menurunkan tingkat stres yang dimiliki oleh lansia berpenyakit kronis.

Melalui wawancara 11 November 2017 di Yayasan Rumah Sehat Orbit Surabaya terhadap empat subyek pengguna narkoba, dapat diketahui gejala - gejala stres yang dialami klien. Subyek pertama yaitu NR berusia 17 tahun sudah menjalani rehabilitasi selama 2 bulan. Gejala ang dialami NR yaitu mengalami kaku di bagian leher belakang, mudah merasa lelah, daya tahan tubuh menurun, sering mengalami nervous/gugup, suka konsentrasi, dan merasa gelisah secara terus menerus karena memikirkan keluarga.

Subyek kedua yaitu DB berusia 17 tahun. DB sudah dua bulan menjalani proses rehabilitasi. Dari hasil wawancara DB mengaku bahwa ia sering mengalami sakit kepala, susah tidur dan tidak nyenyak, leher sering sakit, daya tahan tubuh menurun, susah konsentrasi, merasa gelisah karena ingin kebali normal, ingatannya juga sedikit lemah, suasana hati berubah - ubah, tetapi DB merasa senang karena dukungan orang sekitar apalagi teman - teman yang ada di panti rehab yang berinteraksi sangat baik dengan DB.

Subyek ketiga yaitu MF beruusia 16 tahun. MF sudah 3 bulan menjalani proses pemulihan. MF mengaku pada saat baru masuk di panti rehabilitasi ia sering sakit kepala, mengalami gangguan tidur, nafsu makan berkurang, perasaan gelisah karena rasa mengecewakan orang tua dan rasa penyesalan yang mengganggu pikiran. Tetapi MF sampai saat ini mampu beradaptasi karena orang - orang yang ada di panti rehab memperlakukan MF dengan baik dan saling mendukung.

Subyek ke empat yaitu JH yang berusia 30 tahun. JH baru satu minggu menjalani proses rehabilitasi di Yayasan Rumah Sehat Orbit Surabaya. Ia mengaku susah untuk tidur, mudah lelah, nafsu makan meningkat, ia merasa lebih sehat ketika di panti rehab, JH tidak mengalami gugup, selalu aktif mengikuti kegiatan yang ada, mempunyai konsentrasi yang baik, ia merasa gelisah sehingga susah tidur, ingatan $\mathrm{JH}$ masih bagus.

Subyek ketiga yaitu MF beruusia 16 tahun. MF sudah 3 bulan menjalani proses pemulihan. MF mengaku pada saat baru masuk di panti rehabilitasi ia sering sakit kepala, mengalami gangguan tidur, nafsu makan berkurang, perasaan gelisah karena rasa mengecewakan orang tua dan rasa penyesalan yang mengganggu pikiran. Tetapi MF sampai saat ini mampu beradaptasi karena orang - orang yang ada di panti rehab memperlakukan MF dengan baik dan saling mendukung.

Subyek ke empat yaitu JH yang berusia 30 tahun. JH baru satu minggu menjalani proses rehabilitasi di Yayasan Rumah Sehat Orbit
Surabaya. Ia mengaku susah untuk tidur, mudah lelah, nafsu makan meningkat, ia merasa lebih sehat ketika di panti rehab, JH tidak mengalami gugup, selalu aktif mengikuti kegiatan yang ada, mempunyai konsentrasi yang baik, ia merasa gelisah sehingga susah tidur, ingatan $\mathrm{JH}$ masih bagus.

Dr. Robert J. Van Amberg (dalam file:///I:/09410165_Bab_2.pdf) membagi tahapan stres sebagai berikut :

\section{a. Stres Tahap I}

Merupakan tahapan stress yang paling ringan dan biasanya disertai perasaan - peasaan sebagi berikut : semangat bekerja, penglihatan tajam, mampu menyelesaikan pekerjaan lebih dari biasanya, namun tanpa disadari cadangan energy semakin menipis.

\section{b. Stres Tahap II}

Dalam tahap ini dampatk/respon terhadap stressor yang semula menyenangkan tiba - tiba menghilang dan timbul keluhan - keluhan yang disebabkan karena cadangan energy yang tidak lagi cukup sepanjang hari, karena tidak cukup waktu untuk istirahat. Merasa letih sewaktu bangun pagi yang seharusnya merasa segar, merasa mudah lelah sesudah makan siang, lekas merasa lelah menjelang sore hari, sering mengeluh lambung/perut tidak nyaman, dan detakan jantung lebih keras dari biasanya, otot pungggung sakit, tidak mudah santai.

\section{c. Stres Tahap III}

Gangguan lambung semakin terasa nyatamisalkan maag, ketegangan otot semakin terasa, perasaan ketidaktenangan dan ketegangan emosional semakin meningkat, gangguan pola tidur, badan terasa lelah, mudah sakit.

\section{d. Stres Tahap IV}

Untuk bertahan sepanjang hari saja sudah sulit, aktivitas pekerjaaan yang semula menyenangkan-menjadi membosankan, yang semula tanggap situasi menjadi kehilngan kemampuan untuk merespon secara aktif, ketidak mampuan melaksanakan kegiatan sehari - hari, gangguan pola tidur disertai dengan mimpi - mimpi yang menegangka. Seringkali menolak ajakan karena tiada semangat dan gairah.

\section{e. Stres Tahap V}

Bila keadaan berlanjut, maka seseorang akan jatuh dalam stress pada tahap $\mathrm{V}$ yang ditandai dengan gejala - gejala kelelahan fisik dan mental semakin mendalam, ketidkmampuan untuk menyelesaikan pekerjaan sehari - hari yang ringn dan sederhana, ganggan sistem pencernaan semakin berat, timbul perasaan ketakutan, cemas yang semakin meningkat,mudah bingung dan panik.

\section{f. Stres Tahap VI}


Tahap ini merupakan tahapan klimaks seseorang mengalami serangan panik dan rasa takut mati. Gambaran stres tahap VI ini adlah debaran jantung teramat keras, susah bernafas, sekujur badan terasa bergetar, dingin, keringat bercucuran, tidak ada tenaga untuk hal - hal yang ringan, pingsan atau kolaps.

Berdasarkan tahap stres diatas jika dibandingkan dengan gejala yang sedang dialami oleh klien selama proses rehabilitasi, klien sedang mengalami stress pada tahap ke III dengan gejala sebagai berikut : Gangguan lambung semakin terasa nyatamisalkan maag, ketegangan otot semakin terasa, perasaan ketidaktenangan dan ketegangan emosional semakin meningkat, gangguan pola tidur, badan terasa lelah, mudah sakit.

\section{SIMPULAN}

Stres menunjuk pada peristiwa yang dirasakan membahayakan individu, saat individu diharapkan pada situasi stress, maka individu akan bereaksi baik secara fisiologis maupun psikologis. Stres sebagai sebuah gejala yang timbul akibat adanya kesenjangan antara realitas dan ideal, antara keinginan dan kenyataan, antara tantangan dan kemampuan, antara peluang dan potensi. Untuk mengetahui klien mengelamai stres atau tidak perlu mengenali gejala gejalanya terlebih dahulu. Penelitian ini mengguanakan studi literatur dengan mencari referensi teori yang relefan dengan kasus atau permasalahan yang ditemukan.

\section{Daftar Pustaka}

Cance Mc, Kathryn L, and Jane S. 1994.

Stress and Disease in "Pathophysiology". USA: Mosby 304- 307

Dunn AJ. 1995. Interctions between The

Nervous Syatem ant The Immune System. New York: Psychopharmacology. Raven Press. 721-723

file://C:/Users/USER/Downloads/infodat n\%20narkoba\%202017\%20(1).pdf

file:///I:/09410165_Bab_2.pdf. Diakses pada 21 Desember 2017 pukul 23.30 WIB

Haass-Koffler. C.L. and Bartlett S E, 2012.

Stress and Addiction: contribution of the corticotrophin releasing factor (CRF) system in neuroplasticity. Front Mol Neurosci. 5:91.

Hanum. Penerapan Manajemen Stres

Berkelompok dalam Menurunkan Stres pada Lanjut Usia Berpenyakit Kronis. Jurnal Psikologi Volume 43, Nomor 1. 2016

KBBI. Sofware offline
Stres Dan Addiction. Jurnal Unnes Vol 4 No.1 (2012)

Nawangsih \& Putri Rismala. Stres Pada

Mantan Pengguna Narkoba Yang Menjalani Rehabilitasi. Jurnal Psikologi Undip Vol.15 No.2 (2016)

Nursalim. 2013. Strategi dan Intervensi

Konseling. Surabaya : Akademia Permata

Stocker S. 2012. Studies Link Stress And

Drug Addiction. NIDA Research Finding 14:1-4

Taylor.1991.https://www.academia.edu/8

10035/GEJALA_DAN_PENYEBAB_TE

RJADINYA_STRES. Diakses pada 21

Desember 2017 pukul 01.00 WB

Undang-Undang Nomor 35 Tahun 2009

Pasal 103 ayat (2) tentang Narkotika.http://ejournal.uajy.ac.id/9034/1

/JURNALHK10324.pdf diakses pada 28

November 2017 pukul 06.48

Lisdiana. Regulasi Kortisol Pada Kondisi 